University of Montana

ScholarWorks at University of Montana

$5-1991$

\title{
Bird Populations in Logged and Unlogged Western Larch/ Douglas-fir Forest in Northwestern Montana
}

\author{
Bret W. Tobalske \\ University of Montana - Missoula, bret.tobalske@mso.umt.edu \\ Richard L. Hutto \\ University of Montana - Missoula, hutto@mso.umt.edu \\ Raymond C. Shearer
}

Follow this and additional works at: https://scholarworks.umt.edu/biosci_pubs

Part of the Biology Commons

Let us know how access to this document benefits you.

\section{Recommended Citation}

Tobalske, Bret W.; Shearer, Raymond C.; Hutto, Richard L 1991. Bird populations in logged and unlogged western larch/Douglas-fir forest in northwestern Montana. Res. Pap. INT-GTR-442. Ogden, UT: U.S. Department of Agriculture, Forest Service, Intermountain Research Station. 12 p.

This Report is brought to you for free and open access by the Biological Sciences at ScholarWorks at University of Montana. It has been accepted for inclusion in Biological Sciences Faculty Publications by an authorized administrator of ScholarWorks at University of Montana. For more information, please contact scholarworks@mso.umt.edu. 
A13.78: INT-442 cop. ${ }^{2}$

\section{United States \\ Department \\ of Agriculture \\ Forest Service \\ Intermountain \\ Research Station \\ Research Paper \\ INT-442 \\ Bird Populations in Logged and Unlogged Western Larch/Douglas-fir Forest \\ May 1991 in Northwestern Montana}

近霜

\author{
Bret W. Tobalske \\ Raymond C. Shearer \\ Richard L. Hutto
}

UNIVERSITY OF MONTANA LIBRARY

AUG 261991

\section{DOCUMENTS DIVISION}

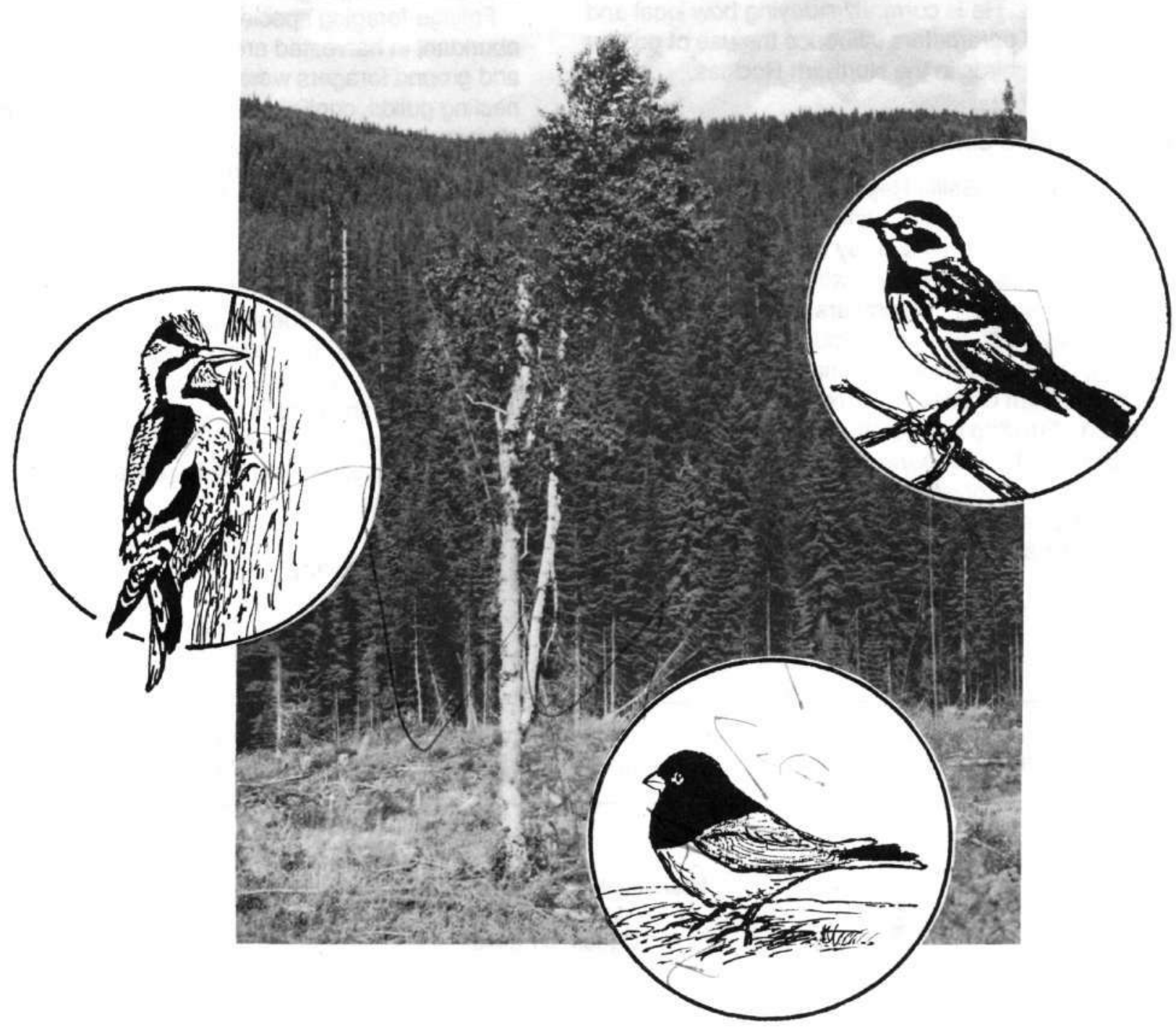




\section{Bird Populations in Logged and Unlogged Western Larch/ Douglas-fir Forest in Northwestern Montana}

\author{
Bret W. Tobalske \\ Raymond C. Shearer \\ Richard L. Hutto
}

\section{INTRODUCTION}

The influence of logging on breeding-season bird populations has been documented for a variety of forest types in the Western United States: mixed conifer (Franzreb and Ohmart 1978; Mannan and Meslow 1984; Verner and Larson 1989), coastal Douglas-fir (Pseudotsuga menziesii) (Hagar 1960; Meslow 1978), interior Douglas-fir (Medin 1985; Medin and Booth 1989), giant sequoia (Sequoiadendron giganteum) (Kilgore 1971), lodgepole pine (Pinus contorta) (Austin and Perry 1979), and ponderosa pine (Pinus ponderosa) (Szaro and Balda 1979).

Medin (1985) provided a summary of bird species' responses to various logging methods based on several of the cited studies. Although general patterns of response were evident for many species, certain species, including yellow-rumped warbler (scientific names of bird species censused in the study area are in the appendix) and hairy woodpecker were reported to increase, decrease, or show no response following clearcutting. This suggests that studies of bird responses to logging may be spatially or temporally specific. Thus, a need exists for other investigations of the effects of logging on birds, especially in unstudied forest types.

Recently we studied the influence of logging on a wide range of birds in the Coram Experimental Forest, located within the western larch (Larix occidentalis) forest cover type (Eyre 1980). This report describes 2 years of observed differences in the avian assemblage following logging and sitepreparation treatments.

\section{STUDY AREA}

This study was located within the southern quarter of the Coram Experimental Forest (CEF), about 28 miles $(45 \mathrm{~km}$ ) east of Kalispell, MT, on the Flathead National Forest (fig. 1). It includes both the Terrace Hill sale area (THSA) and the adjacent Coram Research Natural Area (CRNA) (fig. 2).

\section{Description}

The site occupies a portion of the watershed drained by the South Fork of Abbot Creek. The THSA ranges in elevation from 3,360 to $4,500 \mathrm{ft}$ $(1,021$ to $1,372 \mathrm{~m})$, lies mostly southwest of Abbot Creek, and is on northeast-facing slopes. The CRNA ranges in elevation from 3,500 to $4,458 \mathrm{ft}$ (1,067 to 1,359 m), lies northeast of Abbot Creek, and is mostly on southwest-facing slopes. Slopes of both areas range from 5 to 35 percent. Annual precipitation averages 34 inches $(86 \mathrm{~cm})$. Temperature averages $60^{\circ} \mathrm{F}\left(16^{\circ} \mathrm{C}\right)$ from May through August (Hungerford and Schlieter 1984).

The study area represents a seral stage of the subalpine fir/queencup beadlily (Abies lasiocarpal Clintonia uniflora) habitat type classified by Pfister and others (1977). Western larch and Douglas-fir (Pseudotsuga menziesii var. glauca) are the dominant trees on the CEF. The old-growth larch is composed mostly of 300-year-old trees and occasionally of 500-year-old veterans. Other trees include Engelmann spruce (Picea engelmannii), subalpine fir, lodgepole pine (Pinus contorta), western white pine (Pinus monticola), paper birch (Betula papyrifera), quaking aspen (Populus tremuloides), and black cottonwood (Populus trichocarpa). Dominant shrubs include Rocky Mountain maple (Acer glabrum) and fool's huckleberry (Menziesia ferruginea). Queencup beadlily and pinegrass (Calamagrostis rubescens) are the primary herbs. 


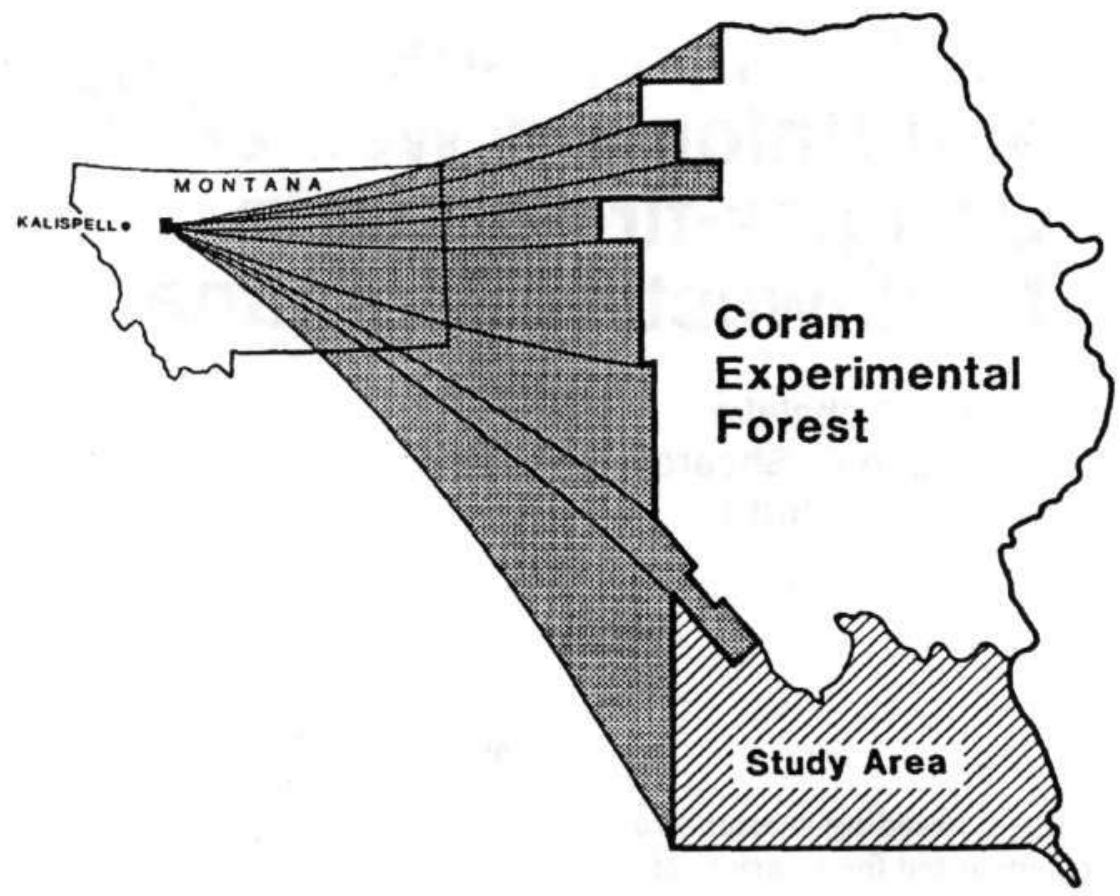

Figure 1-Location of study area within Coram Experimental Forest, northwestern Montana.

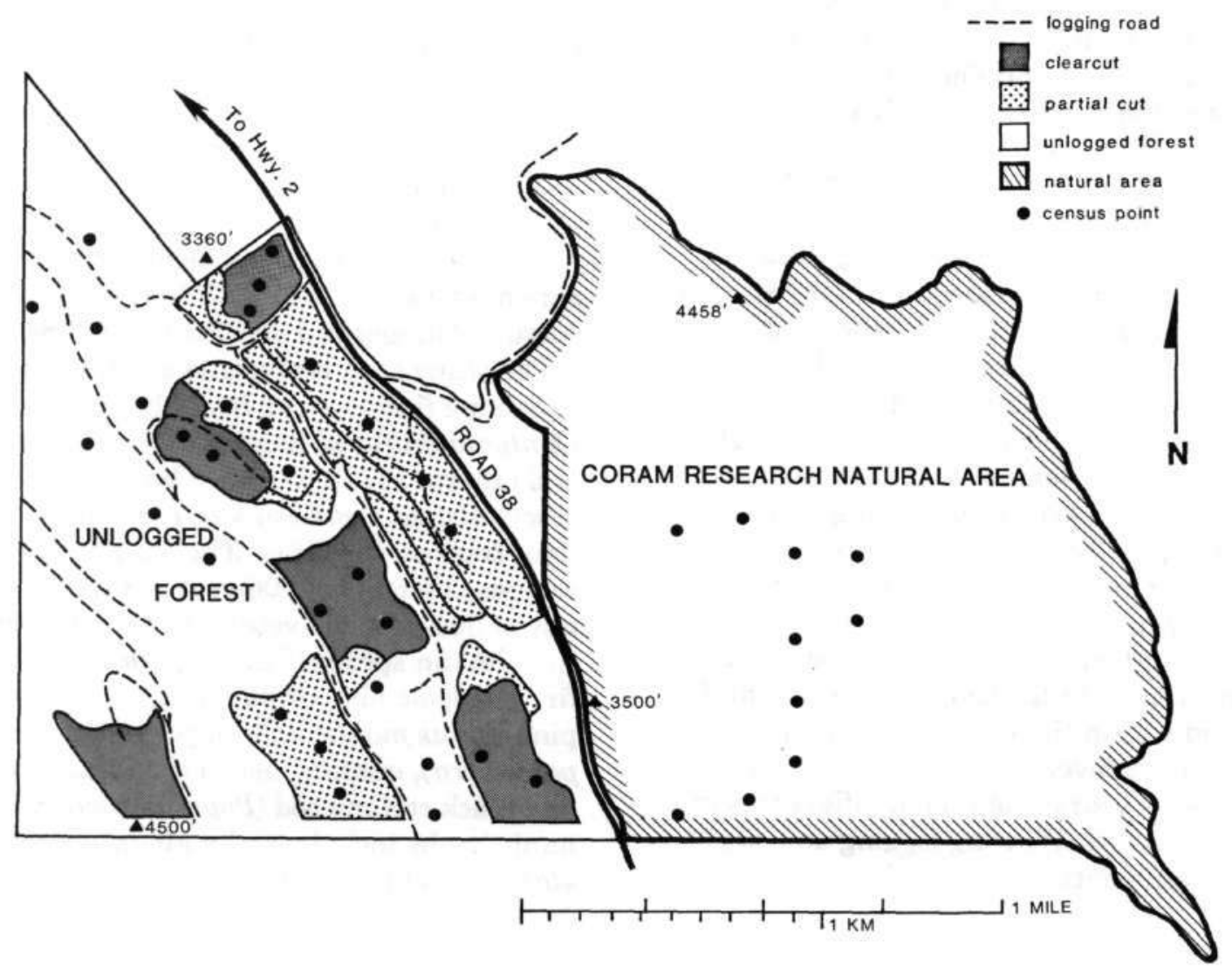

Figure 2-Posttreatment stand conditions and location of bird-count/ vegetation sampling points on the Terrace Hill sale area and Coram Research Natural Area, Coram Experimental Forest, 1989 and 1990. 


\section{TREATMENTS}

The THSA was initially harvested from 1942 to 1944 , leaving three to five seed trees over 12 inches $(31 \mathrm{~cm})$ d.b.h. per acre $(0.4 \mathrm{ha})$ (Fredeking 1953). The seed trees and trees that were unmerchantable in the 1940's were removed in the winter of 1988-89 within partial-cut units, and more extensive overstory removal occurred in the clearcut units. Based on guidelines for the management of cavity-nesting birds by McClelland and Frissell (1975), snags of all species of trees, along with living paper birch, quaking aspen, and black cottonwood, were retained in the cutting units during the recent harvest (figs. 3 and 4).

The THSA was 650 acres ( $263 \mathrm{ha}$ ) and included clearcut and partially cut units along with unlogged forest (fig. 1). There were five clearcuts ranging from 14 to 35 acres ( 6 to $14 \mathrm{ha}$ ). The largest partialcut unit was 70 acres $(28 \mathrm{ha})$, and eight others ranged between 5 and 40 acres ( 2 and $16 \mathrm{ha}$ ). Experimental controls were provided by the unlogged forest of 330 acres (134 ha) within the THSA and the adjacent 837-acre (339-ha) CRNA.

Slash piling and scarification of the units was accomplished with a bulldozer in 1989. Most of the slash piles were burned during the autumn of 1989 , and sites with slopes greater than 20 percent were broadcast burned in September 1990.

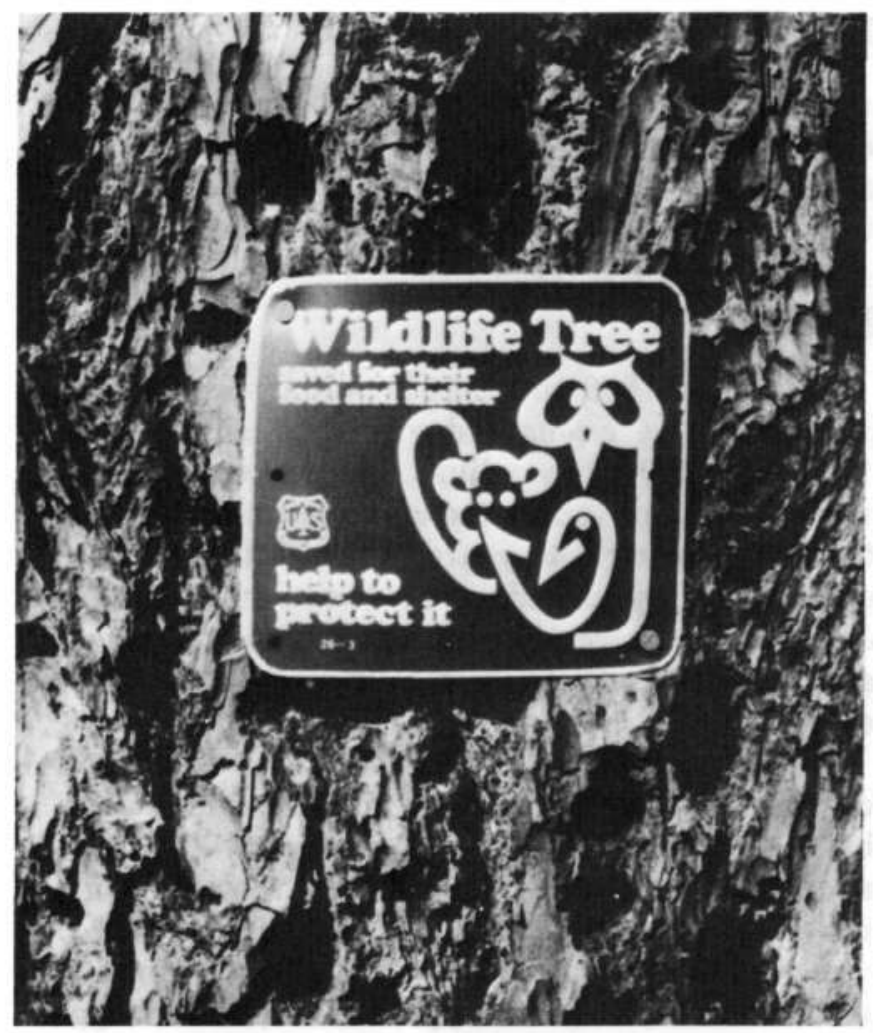

Figure 3-Evidence of woodpecker foraging surrounds a wildlife tree marker on a western larch snag. The snag was retained for wildlife use within a clearcut on the Terrace Hill sale area.

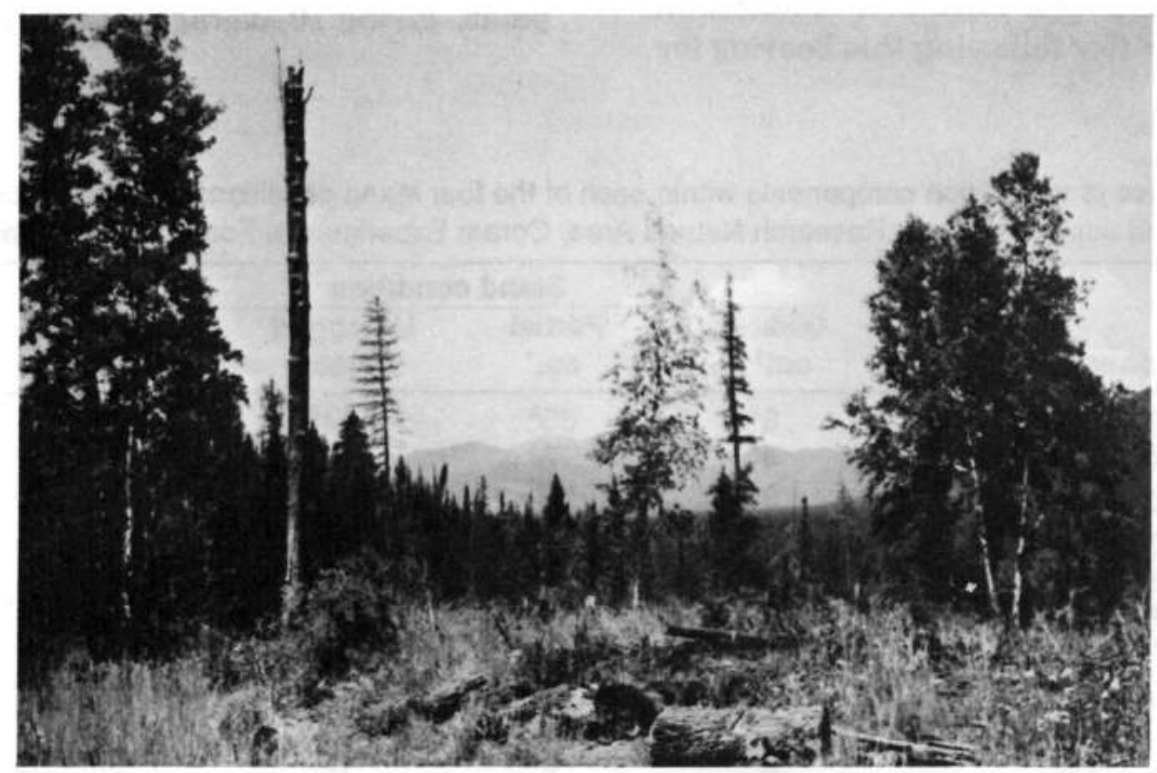

Figure 4-Clearcut stand on the Terrace Hill sale area, with western larch snags and living paper birch retained for wildlife use. 


\section{METHODS}

Tobalske collected field data on bird populations and vegetation characteristics for this study. Our statistical analysis was selected to quantify differences among stand conditions in the study area.

\section{Design}

During the 1989 and 1990 breeding seasons, bird populations were censused with fixed-point counts 109 yards $(100 \mathrm{~m})$ in radius. Species detections were by sight or sound, including birds in flight over the plot. During both years, each point was visited on three evenly spaced days between June 1 and July 7. Counts were done between one-half hour after sunrise and 10 a.m., for a period of 10 minutes each.

Count points were located with a coordinate grid overlay placed on figure 2. After scaling distances between lines on the grid to be 218 yards $(200 \mathrm{~m}$ ) apart on the ground and numbering the points of intersection sequentially, a random-numbers table was read to select 10 points within each of three stand conditions: clearcut, partial-cut, and unlogged forest. Points were selected so that the radius of the plot would not intersect another stand condition. These points defined the census plots on the ground; each was marked at the center with a survey flag.

Because the CRNA (fig. 2) was difficult to map accurately, a different method was used there to select census points. Beginning at the southwest corner of the natural area stand, a random number was generated with a pocket calculator to determine a compass bearing. After following this bearing for
273 yards $(250 \mathrm{~m})$, a census plot was centered at the destination. Subsequent plots were selected in the same manner with a new bearing for all 10 points. Bearings that would carry a plot within 109 yards $(100 \mathrm{~m})$ of the boundary of the natural area were ignored by returning to the origin and taking a new bearing.

Vegetation was sampled once per year during July 1989 and 1990 at the 10 points in each stand condition that were selected for bird censusing (table 1). Sampling followed the guidelines of the Ocular Method in Hahn and Jensen (1987) using the General Plot Data and Ocular Plant Species Data forms. Each plot had a 37-ft (11-m) radius, with one plot at the center of each bird-count point. Snags were included in all tree measurements. Tree basal area was estimated with a "Relascope" prism, and average dominant tree d.b.h. was determined through diameter-tape measurements of five trees, or the maximum number left standing if fewer than five Percentage of cover was measured for trees, shrubs, graminoids, and forbs, using horizontal estimates of the vertical projection of each life form. Tree and shrub cover was further sampled at three height categories: pole and larger, sapling, and seedling tree classes, and tall, mid, and low shrub classes.

\section{Analysis}

The mean count per point for each bird species censused in 1989 and 1990 was calculated by averaging data for the three yearly visits to each point, giving 10 average counts for each bird

Table 1-Estimates of vegetation components within each of the four stand conditions at the Terrace Hill study area and adjacent Coram Research Natural Area, Coram Experimental Forest, in 1989 and 1990

\begin{tabular}{|c|c|c|c|c|c|}
\hline \multirow[b]{2}{*}{ Vegetation component } & \multicolumn{4}{|c|}{ Stand condition } & \multirow[b]{2}{*}{$\begin{array}{l}\text { Proba- } \\
\text { bllfty }\end{array}$} \\
\hline & $\begin{array}{l}\text { Clear- } \\
\text { cut' }\end{array}$ & $\begin{array}{l}\text { Partlal- } \\
\text { cut' }\end{array}$ & $\begin{array}{l}\text { Unlogged } \\
\text { forest }\end{array}$ & $\begin{array}{c}\text { Natural } \\
\text { area }\end{array}$ & \\
\hline Tree basal area $\left(\mathrm{ft}^{2} / \mathrm{acr} \theta\right)$ & $8^{4}$ & $35^{\wedge}$ & $104^{B}$ & $112^{8}$ & 0.001 \\
\hline Tree d.b.h. of dominant tree (inches) & $4^{A}$ & $7^{\wedge}$ & $14^{\mathrm{B}}$ & $15^{\mathrm{B}}$ & .001 \\
\hline Tree total cover (percent) & $3^{A}$ & $24^{B}$ & $59^{\mathrm{C}}$ & $63^{c}$ & .001 \\
\hline Pole and larger (percent) & $1^{A}$ & $18^{\mathrm{B}}$ & $44^{c}$ & $48^{c}$ & .001 \\
\hline Sapling (percent) & $1^{A}$ & $5^{\wedge}$ & $13^{B}$ & $13^{8}$ & .001 \\
\hline Seedling (percent & 1 & 2 & 2 & 2 & 1.000 \\
\hline Shrub total cover (percent) & $13^{\lambda}$ & $37^{8}$ & $47^{\mathrm{B}}$ & $44^{8}$ & .006 \\
\hline Tall ${ }^{3}$ (percent) & $1^{A}$ & $9^{\wedge 8}$ & $10^{\mathrm{AB}}$ & $13^{B}$ & .016 \\
\hline Mid ${ }^{3}$ (percent) & 10 & 22 & 25 & 18 & .192 \\
\hline Low (percent) & $2^{\wedge}$ & $6^{A B}$ & $12^{\mathrm{a}}$ & $12^{\mathrm{B}}$ & .016 \\
\hline Graminoid total cover (percent) & 9 & 11 & 6 & 4 & 1.000 \\
\hline Forb total cover (percent) & 22 & 18 & 35 & 42 & .032 \\
\hline
\end{tabular}

'Tree snags of all species and living paper birch trees were left standing where possible.

'Low probability values indicate significantly different means among stand conditions, Bonferroni adjusted to control for experimentwise error (SPSS Inc. 1983); superscript letters group similar means for each vegetation component.

${ }^{3}$ Tall shrub, >10 ft ( $\left.3 \mathrm{~m}\right)$; midshrub, 2 to $10 \mathrm{ft}(0.6$ to $3 \mathrm{~m})$; low shrub, $<2 \mathrm{ft}(0.6 \mathrm{~m})$ (Hahn and Jensen 1987 ). 
species within each stand condition and year. The mean of each of these $\mathbf{1 0}$ averages was used to test for differences in relative abundance of bird species among stand conditions and years. Sampling vegetation components at the census points once per year generated 10 sample values for the selected variables within each stand condition. The mean of each set of 10 samples was compared to the means for the other stands during each year.

All bird species seen less than eight times during both years' censusing over all points were arbitrarily excluded from species-level statistical analysis (table 2). These species were included in the guild analysis (table 3). Statistical significance in all tests was $P<0.05$, employing the Bonferroni adjustment to control for experimentwise error rate (SPSS Inc. 1983). We used two-way analysis of variance to test for significant interaction and main effects for a given species' abundance by stand condition and year (SPSS Inc. 1983). Parametric analysis was justified on the basis of normal probability plots for the common species within the sample. Although count data is heavily rightskewed, the analysis of variance procedure is robust for comparison of samples with similar distributions (Sokal and Rohlf 1981).

Table 2-Mean number of birds counted per census point within the four stand conditions at the Terrace Hill study area and adjacent Coram Research Natural Area, Coram Experimental Forest, in 1989 and 1990

\begin{tabular}{|c|c|c|c|c|c|c|c|}
\hline \multirow{2}{*}{ Species' } & \multirow[b]{2}{*}{$\begin{array}{c}\text { Foraging } \\
\text { gulld }^{2}\end{array}$} & \multirow[b]{2}{*}{$\begin{array}{l}\text { Nesting } \\
\text { gulld }^{3}\end{array}$} & \multicolumn{4}{|c|}{ Stand condition } & \multirow[b]{2}{*}{$\begin{array}{l}\text { Proba- } \\
\text { blitity }\end{array}$} \\
\hline & & & $\begin{array}{l}\text { Clear- } \\
\text { cut' }\end{array}$ & $\begin{array}{c}\text { Partlal- } \\
\text { cut }^{4}\end{array}$ & $\begin{array}{l}\text { Unlogged } \\
\text { forest }\end{array}$ & $\begin{array}{c}\text { Natural } \\
\text { Area }\end{array}$ & \\
\hline Killdeer & GF & GR & 0.15 & 0 & 0 & 0 & 0.640 \\
\hline Vaux's switt & FC & SC & .15 & .07 & 0 & 0 & 1.000 \\
\hline Red-naped sapsucker & TO & PC & .45 & .35 & .27 & .52 & 1.000 \\
\hline Hairy woodpecker & TD & PC & .17 & .13 & .19 & .33 & 1.000 \\
\hline Northern flicker & GF & PC & .22 & .13 & .07 & .18 & 1.000 \\
\hline Olive-sided flycatcher & FC & CB & .17 & .07 & .02 & 0 & .224 \\
\hline Western wood-powee & FC & $\mathrm{CB}$ & .07 & .03 & .05 & 0 & 1.000 \\
\hline Tree swallow & FC & sc & $.62^{\mathrm{A}}$ & $.07^{\mathrm{B}}$ & $0^{8}$ & $0^{8}$ & .016 \\
\hline Steller's jay & $\mathbf{F F}$ & CB & .03 & .05 & .13 & .05 & 1.000 \\
\hline Common raven & GF & CB & .11 & .03 & .10 & .22 & 1.000 \\
\hline Black-capped chickadeo & TG & SC & .30 & .27 & .40 & .57 & 1.000 \\
\hline Mountain chickadee & TG & SC & .08 & .17 & .28 & .28 & 1.000 \\
\hline Red-breasted nuthatch & TG & SC & .30 & .42 & .58 & .53 & 1.000 \\
\hline Brown creeper & TG & $\mathrm{SC}$ & 0 & .03 & .02 & .12 & 1.000 \\
\hline Winter wren & GF & GR & 0 & .13 & .08 & 17 & 1.000 \\
\hline Golden-crowned kinglet & FF & CT & $\alpha^{a}$ & $.45^{\wedge \mathrm{B}}$ & $.47^{\wedge \mathrm{B}}$ & $.73^{\mathrm{B}}$ & .016 \\
\hline Ruby-crowned kinglet & FF & CT & $.13^{\wedge}$ & $.52^{\mathrm{B}}$ & $.40^{\wedge \mathrm{B}}$ & $.17^{\wedge}$ & .016 \\
\hline Mountain bluebird & GF & SC & 13 & 0 & 0 & .03 & 1.000 \\
\hline Townsend's solitaire & FF & GR & .13 & .25 & 0 & .02 & .192 \\
\hline Swainson's thrush & FF & CB & $.15^{\mathrm{A}}$ & $1.05^{8}$ & $1.05^{\mathrm{B}}$ & $1.23^{\mathrm{B}}$ & .002 \\
\hline American robin & GF & BT & .58 & .30 & .22 & .05 & .096 \\
\hline Varied thrush & GF & BT & $.03^{\wedge}$ & $.05^{\mathrm{A}}$ & $.10^{\mathrm{A}}$ & $.38^{\mathrm{B}}$ & .016 \\
\hline Solitary vireo & FF & $\mathrm{CB}$ & .05 & .10 & .07 & .18 & 1.000 \\
\hline Warbling vireo & FF & BT & .13 & .20 & .18 & .18 & 1.000 \\
\hline Yellow-rumped warbler & FF & CT & .28 & .35 & .28 & .25 & 1.000 \\
\hline Townsend's warbler & FF & CT & $.43^{\wedge}$ & $1.00^{8}$ & $1.22^{\mathrm{BC}}$ & $1.50^{\mathrm{c}}$ & .002 \\
\hline MacGillivray's warbler & FF & BT & .02 & .12 & .13 & .22 & .864 \\
\hline Western tanager & FF & $\mathrm{CT}$ & .10 & .20 & .10 & 0 & .896 \\
\hline Chipping sparrow & GF & BT & $.68^{\mathrm{A}}$ & $.72^{A}$ & $.52^{\wedge 1}$ & $.17^{8}$ & .016 \\
\hline Fox sparrow & GF & GR & $.18^{\mathrm{A}}$ & $.32^{\mathrm{AB}}$ & $.40^{N B}$ & $0^{A}$ & .016 \\
\hline Dark-eyed junco & GF & GR & $1.27^{\mathrm{A}}$ & $.80^{\mathrm{A}}$ & $.25^{\mathrm{B}}$ & $.13^{\mathrm{B}}$ & .002 \\
\hline Pine siskin & FF & $\mathrm{CB}$ & $.78^{\wedge}$ & $.57^{\mathrm{AB}}$ & $.17^{\mathrm{B}}$ & $.08^{\mathrm{B}}$ & .032 \\
\hline Total No. species & 32 & 32 & 29 & 30 & 28 & 25 & \\
\hline
\end{tabular}

'Scientific names of bird species are listed in appendix.

${ }^{2}$ Foraging guild: $F F=$ foliage forager; $F C=$ flycatcher; $T D=$ tree driller; $T G=$ tree gleaner; $G F=$ ground forager (Diem and Zeveloff 1980).

${ }^{3}$ Nesting guild: $\mathrm{CT}=$ conifer tree; $\mathrm{CB}=$ conifer or broadleaf tree; $\mathrm{BT}=$ bush or small tree; $\mathrm{PC}=$ primary cavity; $\mathrm{SC}=\mathrm{seconday}$ cavity; $\mathrm{GR}=$ ground (Diem and Zeveloff 1980).

${ }^{4}$ Tree snags of all species and living paper birch trees were left standing where possible.

${ }^{5}$ Low probability values indicate significantly different means among stand conditions, Bonferroni adjusted to control for experimentwise error; superscript letters group similar means for each species (SPSS Inc. 1983). 
Table 3-Mean number of birds, by guilds, counted per census point within the four stand conditions at the Terrace Hill study area and adjacent Coram Research Natural Area, Coram Experimental Forest, in 1989 and 1990

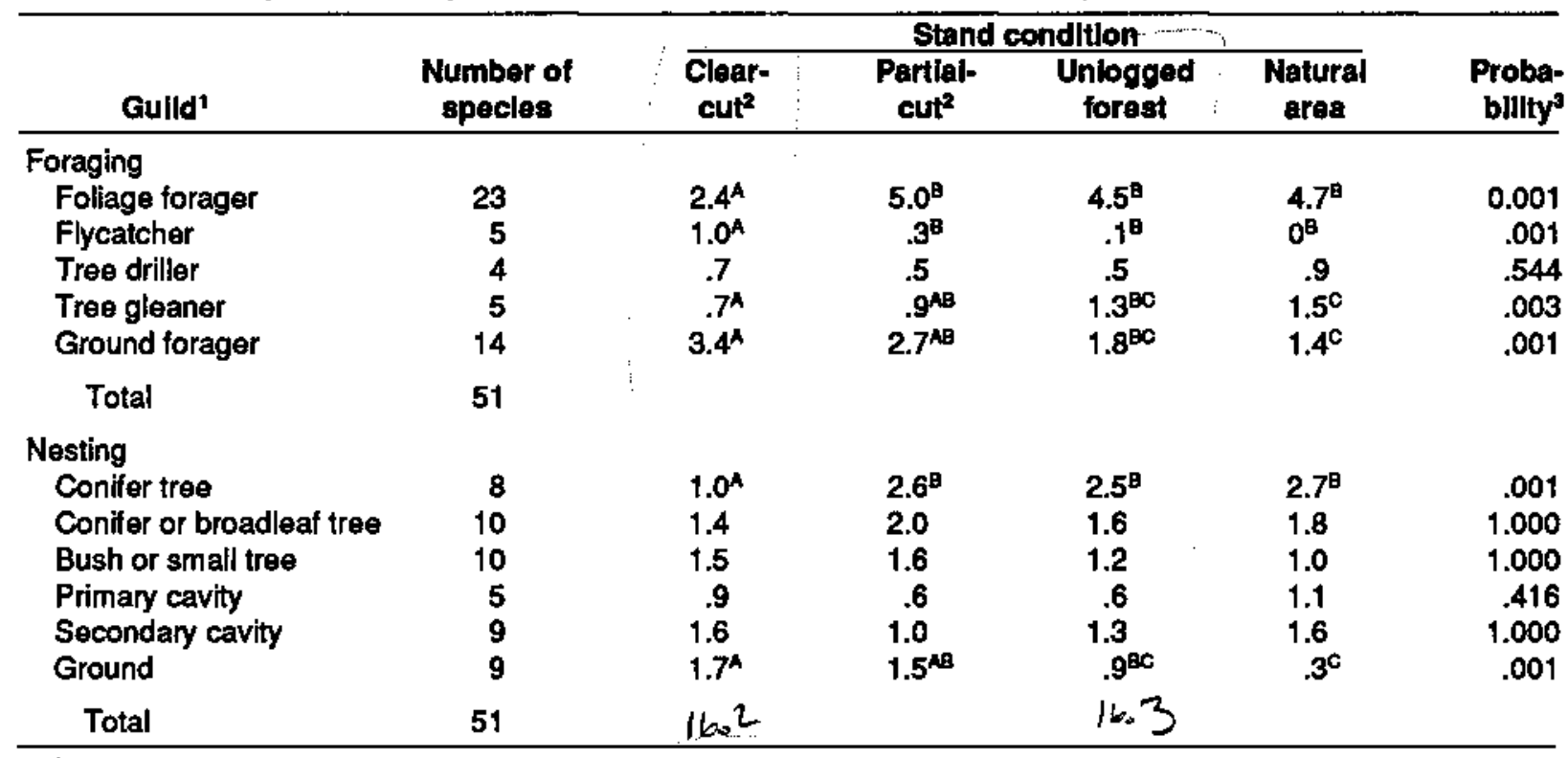

'Guilds adapted from Diem and Zeveloff (1980).

2Trea snags of all species and living paper birch left standing where possible.

'Low probability values indicate significanthy different means among stand conditions, Bonferroni adjusted to control for experimentwise error; superscript letters group similar means for each guild (SPSS Inc. 1983).

The same statistical analysis was used on guild populations (table 3) and vegetation structure (table 1).

\section{RESULTS}

The differences among the stand conditions in the study area are described for bird populations and vegetation components.

\section{Birds}

Tobalske observed 51 bird species during censusing of the study area (appendix), but only 32 species were sufficiently abundant to include in the statistical analysis (table 2). Pine siskins and varied thrushes exhibited a significant interaction effect between stand condition and year. Significant differences in abundance occurred among stand conditions for 10 species of birds. Tree swallows were frequently detected in clearcuts, but virtually absent elsewhere. Species that were less abundant in clearcut or partial-cut areas were golden-crowned kinglet, Swainson's thrush, varied thrush, and Townsend's warbler. Conversely, dark-eyed juncos and pine siskins were more abundant in harvested habitat than elsewhere. Ruby-crowned kinglets and fox sparrows were least abundant in clearcuts and in the CRNA, while chipping sparrows were common in all areas except the CRNA.

Several other species did not exhibit significant differences in abundance, but were less abundant in clearcuts than elsewhere. These include brown creeper, winter wren, and MacGillivray's warbler (table 2). Likewise, species that were more abundant in harvested stands but did not exhibit significant differences include olive-sided flycatcher, Townsend's solitaire, and American robin. Interestingly, robins were least abundant in the CRNA and relatively common in the unlogged forest between harvest units on the THSA.

When species were grouped into foraging guilds, following Diem and Zeveloff (1980), foliage foragers were least abundant in clearcuts. Similarly, tree gleaners were less abundant in clearcuts and partial cuts than in unharvested areas. In contrast, flycatchers and ground foragers were more abundant in harvested habitat, particularly clearcuts. Among the nesting guilds, conifer tree nesters were least abundant in clearcuts and ground nesters were most abundant in cutover sites. Ground nesters and ground foragers had a significant interaction effect between stand conditions and years because of a marked increase in abundance in harvested areas in 1990. 


\section{Vegetation}

Some components of the vegetation varied by stand condition while others did not (table 1). Obviously the cutover areas had significantly less tree basal area and d.b.h. than the uncut controls. The clearcuts had some tree basal area and d.b.h. because, where possible, snags of all species and live paper birch were left for use by birds and animals. Percentage of total tree cover (made up of seedlings, saplings, and pole-size and larger trees) significantly increased from clearcut through partial cut to uncut units. Although the pole-size and larger trees followed this pattern, sapling-size trees were not significantly different between the cutover areas. Seedling cover was not significantly different among stand conditions.

Following timber harvest, total shrub cover (percent) on partial-cut and uncut stands was significantly greater than on clearcuts (table 1). The tall-shrub and mid-shrub components were decreased substantially on clearcuts compared to partial cuts or the uncut controls. Low shrub cover on clearcuts was significantly less than on the uncut stands, and was intermediate (but not significantly different) on partial cuttings.

Neither the graminoid nor the forb cover was significantly different among the stand conditions after the cutting treatments (table 1), but twice as much average graminoid cover occurred on cutover than on uncut areas. Conversely, forb cover within the cutover stands was about half that of the uncut areas.

\section{DISCUSSION}

For the bird species and guilds that exhibited significantly different means among stand conditions, abundance patterns seem biologically reasonable in light of their habitat requirements. For example, tree swallows were most abundant in clearcuts with some snags and birch trees reserved (fig. 4). For these members of the flycatching and secondary-cavity nesting guilds, open, meadowlike habitat with nest-tree resources is probably ideal habitat. Likewise, dark-eyed juncos, as ground foragers and ground nesters, were most abundant in clearcuts and partial-cut units. In contrast, the members of the conifer tree nesting guild, with species like golden-crowned kinglet and Townsend's warbler, were less abundant in clearcuts than elsewhere (tables 2 and 3).

Ruby-crowned kinglets and fox sparrows were most abundant in partial-cut stands and unlogged forests interspersed between the cutting units. Perhaps an increase in edge habitat is beneficial to these species; males of both species were frequently heard singing from conifers adjacent to clearings. Chipping sparrow and American robin were least abundant in the CRNA and relatively abundant in the unlogged forest on the THSA, pointing out that they may favor edge habitat in conjunction with open stands.

The pine siskin, a foliage-foraging and conifer- or broadleaf-tree nesting species showed a significant interaction between habitat and year for abundance, but this was due to a dramatic increase in abundance during 1990 in all habitat categories of the study. This species is known for sporadic, large changes in abundance and irruptive foraging behavior. Abundance of pine siskins within harvested habitat is the result of retaining living birch trees and the small size of the cutting units. These two factors may also have increased the abundance of other members of the conifer/broadleaf tree nesting guild (table 3).

Varied thrushes showed a significant habitat and year interaction for abundance. No varied thrushes were detected while censusing during 1990 even though these birds were relatively common in 1989. Censusing during 1991 may help to clarify which year was unusual for this species on the study area. Varied thrush is the only species among those that were most abundant in unharvested areas to have a significant difference in numbers between the unlogged forest and the natural area (table 2). This may illustrate a qualitative difference for this species between contiguous and fragmented oldgrowth forest.

A habitat and year interaction for abundance was also significant for ground-foraging and groundnesting guilds. The number of ground foragers increased from 1989 to 1990 in clearcut, partial cut, and unlogged forest, but decreased in the CRNA. Numbers of ground nesters also increased more in partially cut areas than elsewhere. These patterns are shifts away from contiguous forest toward harvested and fragmented forest. A time-lag effect following logging, as described for these guilds, seems reasonable in light of the possibility of site tenacity by breeding birds (Atwood and Massey 1988). Adults may be predisposed to return to the same site to breed following migration, and they may not have time immediately upon arrival to search for other potential territories. If this is true, they may correct the situation in late summer when they have time to search for a new site.

Because more than half of the species included in the statistical analysis did not show significant differences in abundance among stand conditions, it is possible that factors related to logging may not affect the majority of species if reserving snags and live trees, and if small harvest units surrounded by 
unlogged forest function as mitigating influences. Other alternatives, however, merit consideration.

A factor that may have contributed to overlooking biologically important differences in abundance was the small sample consisting of 10 replicates within each stand condition. This reduced the power, or the ability to detect differences in means, for our statistical tests. The relative scarcity of many species contributed to this problem. Nineteen species were detected less than eight times during censusing; these were not included in the specieslevel analysis. Nonetheless, among the species included, zero counts at census points were commonplace, and this property of census data, in combination with the small sample size, served to inflate variance and render different sample means statistically indistinguishable.

An example of the conservative nature of our statistical tests is the killdeer, which was detected only at two points in clearcut habitat during both years. As a ground-nesting and ground-foraging species, probably more killdeer will use cleared than uncut habitat, but large variance (mean number counted per point in clearcuts $=0.15$, standard error $=0.08$ ) caused a failure to reject the null hypothesis of equal means. The power for this analysis of variance model was 44 percent, which was rather low. We grouped species into guilds (table 3) to partially circumvent the problem of uncommon species' counts and, as shown in table 3, ground foragers and ground nesters showed a highly significant difference in abundance between habitats. They were especially common in clearcut and partially cut areas.

Even if population sizes do not vary among stand conditions, it is conceivable that the abundance of a species may not be a valid indicator of habitat suitability (Van Horne 1983). A given habitat may act as an ecological sink where individuals experience low reproductive success or high mortality in comparison to more favorable habitats (Wiens and Rotenberry 1981). For example, birds may be abundant in cleared areas but raise fewer offspring per nest than conspecifics in contiguous forest. The resupply of individuals to inadequate habitat from optimal areas could be behaviorally mediated.

Factors that ultimately determine habitat selection include food and cover availability, but Hildén (1965) suggested that vegetation structure is the proximate cue birds use to select territories. Birds arriving during spring in northern latitudes must select nesting territories based on structural features of the habitat rather than a direct assessment of food availability. If we manipulate habitat to provide appropriate cues for these species, we could see birds within the habitat even though it is not suitable. Thus some human-altered environments may function as ecological sinks (Gates and Gysel 1978).

Consider woodpeckers, for example. We detected no difference in abundance between stand conditions for red-naped sapsuckers, hairy woodpeckers, and northern flickers (table 2). A proximate cue that may influence a woodpecker settling into a nesting territory could be the previous year's nest tree. Lawrence (1967), studying yellow-bellied sapsuckers (Sphyrapicus varius) in Ontario, suggested that pair bonds were reestablished through site rather than mate recognition, and females in particular cued in on the former nest tree. Thus, by reserving snags and deciduous timber during the harvest and site preparation treatments on the THSA, adult woodpeckers returning in the spring may have been motivated to establish territories within inadequate habitat. A detailed study that evaluates habitat quality through measures of reproductive success among red-naped sapsuckers is in progress (Tobalske and others 1990).

Wiens and others (1986) suggested that interpretation of a species' response to habitat alteration may depend on the spatial scale of the manipulation. The largest clearcut on the THSA was 35 acres (14 ha) (fig. 2), but commercial clearcuts may cover areas much larger (Dickson and others 1983). Extrapolating the results of a small-scale study to that of a large-scale system is ignoring biological reality. Moreover, landscape-level changes on a very large scale, such as a portion of a State or country, may significantly affect bird species yet be impossible to address without regional data.

\section{MANAGEMENT RECOMMENDATIONS}

The variation in abundance within the community of breeding bird species relative to logged or unlogged stand conditions indicates that management for any particular species or guild will probably fail to provide for the integrity of the entire system. In short, diversity of habitat will likely promote diverse bird assemblages. During timber harvest, tree-dependent bird species are losing access to an important resource, and it is generally this portion of the bird community for which managers seek to mitigate adverse effects.

The most striking feature of the clearcuts on Terrace Hill is the large number of standing larch snags and live paper birch trees (fig. 4). It is feasible that the snags and living trees, along with the small size of the cutting units in relation to interspersed unlogged forest, mitigated the effect of the timber harvest for tree-dependent bird species, ranging from cavity nesters, such as red-naped sapsucker and red-breasted nuthatch, to foliage 
foragers, such as yellow-rumped warbler and western tanager. Therefore, we reiterate the recommendation of McClelland and Frissell (1975) to leave, wherever possible, all snags and nonmerchantable timber including paper birch, quaking aspen, and black cottonwood within cutting units.

Additionally, we have observed a variety of species of birds, including winter wren, Townsend's solitaire, and dark-eyed junco, using unburned slash piles as perches, food sources, or nest sites (figs. 5 and 6). These piles may contribute substantially to the quality of postharvest habitat for certain bird and small mammal species. Further study is required to establish the importance of this potential resource; nonetheless, measures should be taken to retain some slash piles during and after site treatments.

It is beyond the scope and intention of this study to provide quantitative recommendations regarding the optimum number of snags, trees, or slash piles to maintain the integrity of western larch/Douglasfir bird communities when harvesting timber. Research in progress (Tobalske and others 1990) suggests that harvests that mimic naturally occurring habitat, such as an open, wooded meadow, may be appropriate models.

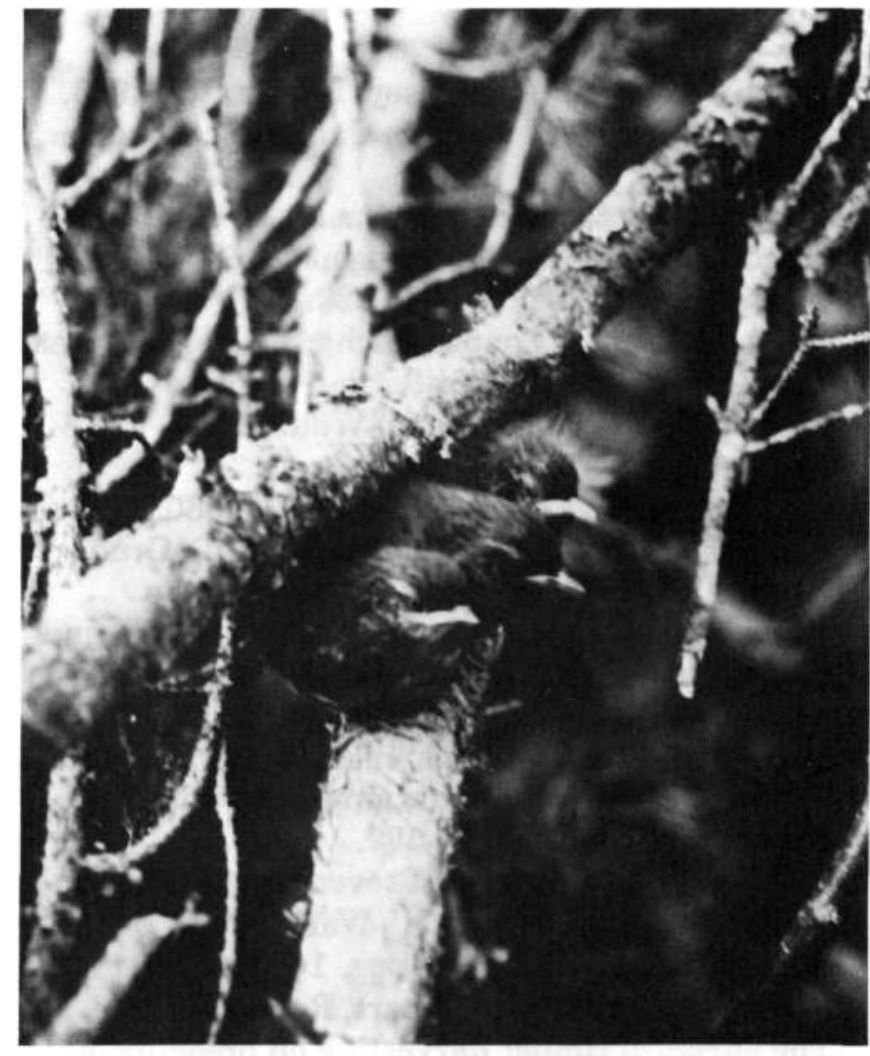

Figure 5-Juvenile winter wrens perched on a branch within a slash pile on the Terrace Hill sale area. Slash piles may provide important cover for several bird species in clearcut and partial-cut stands.

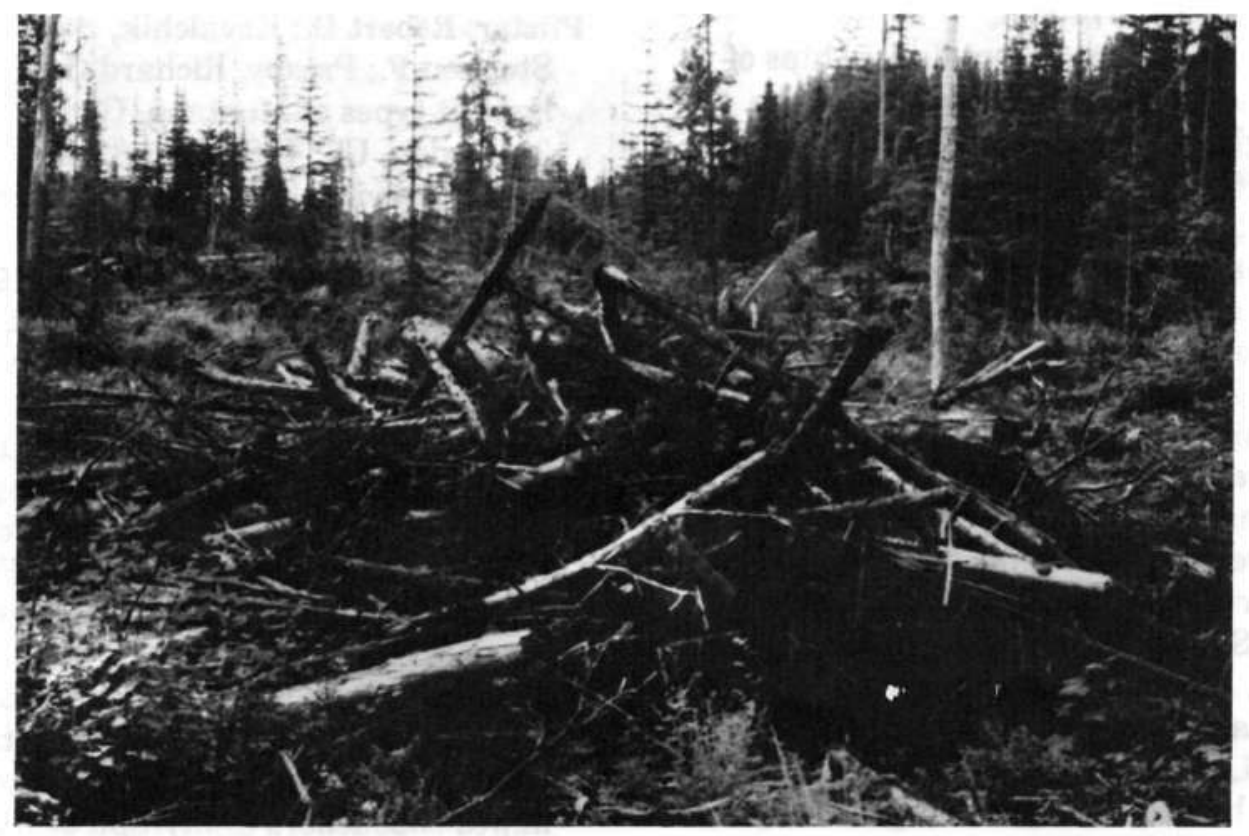

Figure 6-Slash piles such as this were frequently used as perching and foraging sites by several bird species censused within clearcut and partial-cut stands on the Terrace Hill sale area. 


\section{REFERENCES}

Atwood, Johnathan L.; Massey, Barbara W. 1988. Site fidelity of least terns in California. Condor. 90: 389-394.

Austin, Dennis D.; Perry, Michael L. 1979. Birds in six communities within a lodgepole pine forest. Journal of Forestry. 77: 584-589.

Dickson, James G.; Conner, Richard N.; Williamson, J. Howard. 1983. Snag retention increases bird use of a clear-cut. Journal of Wildlife Management. 47: 799-804.

Diem, Kenneth L.; Zeveloff, Samuel I, 1980. Ponderosa pine bird communities. In: DeGraff, Richard M., tech. coord. Proceedings of the workshop on management of western forests and grasslands for nongame birds; 1980 February 11-14; Salt Lake City, UT. Gen. Tech. Rep. INT86. Ogden, UT: U.S. Department of Agriculture, Forest Service, Intermountain Forest and Range Experiment Station: 170-197.

Eyre, F. H., ed. 1980. Forest cover types of the United States and Canada. Washington, DC: Society of American Foresters. 148 p.

Franzreb, Kathleen E.; Ohmart, Robert D. 1978. The effects of timber harvesting on breeding birds in a mixed coniferous forest. Condor. 80: 431-441.

Fredeking, William J. 1953. The development of reproduction following a seed tree cutting of a larch stand in northwestern Montana. Missoula, MT: Montana State University. 64 p. Thesis.

Gates, J. Edward; Gysel, Leslie W. 1978. Avian nest dispersion and fledging success in field-forest ecotones. Ecology. 59: 871-883.

Hagar, Donald C. 1960. The interrelationships of logging, birds, and timber regeneration in the Douglas-fir region of northwestern California. Ecology. 41: 116-125.

Hahn, Wendel J.; Jensen, Mark E. 1987. Ecosystem classification handbook, chapter 4. Missoula, MT: U.S. Department of Agriculture, Forest Service, Northern Region.

Hildén, O. 1965. Habitat selection in birds. Annales Zoologica Fennici. 2: 53-75.

Hungerford, Roger D.; Schlieter, Joyce A. 1984. Weather summaries for Coram Experimental Forest, northwestern Montana-an international biosphere reserve. Gen. Tech. Rep. INT-160. Ogden, UT: U.S. Department of Agriculture, Forest Service, Intermountain Forest and Range Experiment Station. 34 p.

Kilgore, Bruce M. 1971. Response of breeding bird populations to habitat changes in a giant sequoia forest. American Midland Naturalist. 85: 135-152.
Lawrence, Louise de Kiriline. 1967. A comparative life-history study of four species of woodpeckers. Ornithol. Monogr. 5. Washington, DC: American Ornithologist's Union. $130 \mathrm{p}$.

Mannan, R. William; Meslow, E. Charles. 1984. Bird populations and vegetation characteristics in managed and old-growth forest, northeastern Oregon. Journal of Wildlife Management. 48: 1219-1238.

McClelland, B. Riley; Frissell, Sidney S. 1975. Identifying forest snags useful for hole-nesting birds. Journal of Forestry. 73: 414-417.

Medin, Dean E. 1985. Breeding bird responses to diameter-cut logging in west-central Idaho. Res. Pap. INT-355. Ogden, UT: U.S. Department of Agriculture, Forest Service, Intermountain Research Station. $6 \mathrm{p}$.

Medin, Dean E.; Booth, Gordon D. 1989. Responses of birds and small mammals to single-tree selection logging in Idaho. Res. Pap. INT-408. Ogden, UT: U.S. Department of Agriculture, Forest Service, Intermountain Research Station. $11 \mathrm{p}$.

Meslow, E. Charles. 1978. The relationship of birds to habitat structure - plant communities and successional stages. In: DeGraaf, Richard M., tech. coord. Proceedings of the workshop on nongame bird habitat management in the coniferous forests of the western United States; 1977 February 7-9; Portland, OR. Gen. Tech. Rep. PNW-64. Portland, OR: U.S. Department of Agriculture, Forest Service, Pacific Northwest Forest and Range Experiment Station. 19-31. Pfister, Robert D.; Kovalchik, Bernard L.; Arno, Stephen F.; Presby, Richard C. 1977. Forest habitat types of Montana. Gen. Tech. Rep. INT34. Ogden, UT: U.S. Department of Agriculture, Forest Service, Intermountain Forest and Range Experiment Station. $174 \mathrm{p}$.

Sokal, Robert R.; Rohlf, F. James. 1981. Biometry. New York: W. H. Freeman and Company. 859 p. SPSS Inc. 1983. SPSS ${ }^{X}$ user's guide. Chicago: SPSS Inc. $806 \mathrm{p}$.

Szaro, Robert C.; Balda, Russell P. 1979. Effects of harvesting ponderosa pine on nongame bird populations. Res. Pap. RM-212. Fort Collins, CO: U.S. Department of Agriculture, Forest Service, Rocky Mountain Forest and Range Experiment Station. 8 p.

Tobalske, Bret W.; Hutto, Richard L.; Shearer, Raymond C. 1990. The effects of timber harvesting on the reproductive success of rednaped sapsuckers (Sphyrapicus nuchalis): planned research. Northwest Environmental Journal. 6: 398-399. 
Van Horne, B. 1983. Density as a misleading indicator of habitat quality. Journal of Wildlife Management. 45: 893-901.

Verner, Jared; Larson, Terry A. 1989. Richness of breeding bird species in mixed-conifer forests of the Sierra Nevada, California. Auk. 106: 447-463.
Wiens, John A.; Rotenberry, John T. 1981. Censusing and the evolution of avian habitat profitability. Studies in Avian Biology. 6: 522-532. Wiens, John A; Rotenberry, John T.; Van Horne, Beatrice. 1986. A lesson in the limitations of field experiments: shrubsteppe birds and habitat alteration. Ecology, 67: 365-376. 
Red-tailed hawk

Ruffed grouse

Killdeer

Barred owl

Vaux's swift

Rufous hummingbird

Red-naped sapsucker

Hairy woodpecker

Three-toed woodpecker

Northern flicker

Pileated woodpecker

Olive-sided flycatcher

Western wood-pewee

Dusky/Hammond's flycatcher

Tree swallow

Gray jay

Steller's jay

Clark's nutcracker

Common raven

Black-capped chickadee

Mountain chickadee

Chestnut-backed chickadee

Red-breasted nuthatch

Brown creeper

Winter wren

Golden-crowned kinglet

Ruby-crowned kinglet

Mountain bluebird

Townsend's solitaire

Swainson's thrush

American robin

Varied thrush

Solitary vireo

Warbling vireo

Orange-crowned warbler

Yellow warbler

Yellow-rumped warbler

Townsend's warbler

American redstart

Northern waterthrush

MacGillivray's warbler

Wilson's warbler

Western tanager

Black-headed grosbeak

Chipping sparrow

Fox sparrow

Dark-eyed junco

Brown-headed cowbird

Northern oriole

Cassin's finch

Pine siskin
Buteo jamaicensis

Bonasa umbellus

Charadrius vociferus

Strix varia

Chaetura vauxi

Selasphorus rufus

Sphyrapicus nuchalis

Picoides villosus

Picoides tridactylus

Colaptes auratus

Dryocopus pileatus

Contopus borealis

Contopus sordidulus

Empidonax spp.

Tachycineta bicolor

Perisoreus canadensis

Cyanocitta stelleri

Nucifraga columbiana

Corvus corax

Parus atricapillus

Parus gambeli

Parus rufescens

Sitta canadensis

Certhia americana

Troglodytes troglodytes

Regulus satrapa

Regulus calendula

Sialia currucoides

Myadestes townsendi

Catharus ustulatus

Turdus migratorius

Ixoreus naevius

Vireo solitarius

Vireo gilvus

Vermivora celata

Dendroica petechia

Dendroica coronata

Dendroica townsendi

Setophaga ruticilla

Seirus noveboracensis

Oporornis tolmiei

Wilsonia pusilla

Piranga ludoviciana

Pheucticus melanocephalus

Spizella passerina

Passerella iliaca

Junco hyemalis

Molothrus ater

Icterus galbula

Carpodacus casinii

Carduelis pinus 
Tobalske, Bret W.; Shearer, Raymond C.; Hutto, Richard L. 1991. Bird populations in logged and unlogged western larch/Douglas-fir forest in northwestern Montana. Res.

Pap. INT-442. Ogden, UT: U.S. Department of Agriculture, Forest Service, Intermountain Research Station. 12 p.

Of 32 species of abundant breeding birds, populations of 10 species differed significantly between small cutting units and adjacent uncut forest. Foliage foragers and tree gleaners were less abundant in cutting units, while flycatching species and ground foragers were more common there. Of nesting guilds, conifer tree nesters were least abundant in cutting units, and ground nesters were more common there. Results suggest that bird management should consider diverse community-level habitat needs and that if maintenance of tree-dependent species is important, broadleaf trees and snags of all species should be retained.

KEYWORDS: breeding birds, bird habitat, wildlife management, timber harvesting 


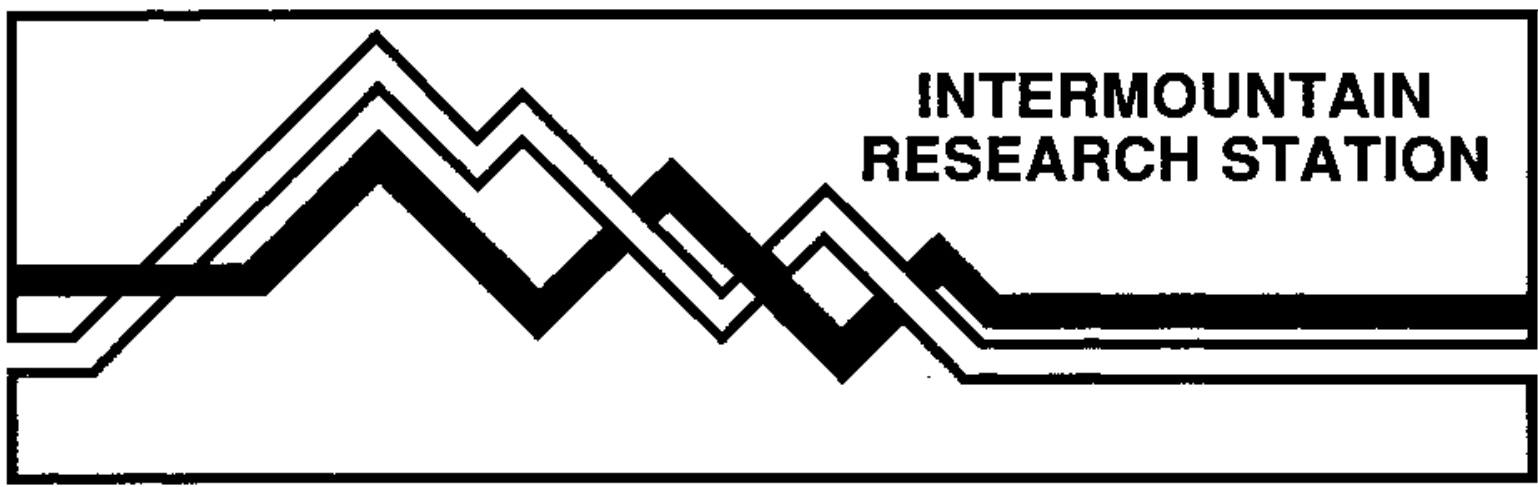

The Intermountain Research Station provides scientific knowledge and technology to improve management, protection, and use of the forests and rangelands of the Intermountain West. Research is designed to meet the needs of National Forest managers, Federal and State agencies, industry, academic institutions, public and private organizations, and individuals. Results of research are made available through publications, symposia, workshops, training sessions, and personal contacts.

The intermountain Research Station territory includes Montana, Idaho, Utah, Nevada, and western Wyoming. Eighty-five percent of the lands in the Station area, about 231 million acres, are classified as forest or rangeland. They include grasslands, deserts, shrublands, alpine areas, and forests. They provide fiber for forest industries, minerals and fossil fuels for energy and industrial development, water for domestic and industrial consumption, forage for livestock and wildlife, and recreation opportunities for millions of visitors.

Several Station units conduct research in additional western States, or have missions that are national or international in scope.

Station laboratories are located in:

Boise, Idaho

Bozeman, Montana (in cooperation with Montana State University)

Logan, Utah (in cooperation with Utah State University)

Missoula, Montana (in cooperation with the University of Montana)

Moscow, Idaho (in cooperation with the University of Idaho)

Ogden, Utah

Provo, Utah (in cooperation with Brigham Young University)

Reno, Nevada (in cooperation with the University of Nevada)

USDA policy prohibits discrimination because of race, color, national origin, sex, age, religion, or handicapping condition. Any person who believes he or she has been discriminated against in any USDA-related activity should immediately contact the Secretary of Agriculture, Washington, DC 20250. 